\title{
RESEARCH ON THE USE OF TANNED LEATHER FIBRES AS AGGREGATE IN OBTAINING ASPHALT MIXTURES
}

\author{
Gabriel ZĂINESCU1 ${ }^{1}$, Rodica Roxana CONSTANTINESCU ${ }^{1}$, Carmen RĂCĂNELL2, Dana DESELNICU ${ }^{3}$
}

${ }^{1}$ INCDTP - Division: Leather and Footwear Research Institute, 93 Ion Minulescu Str., 031215, Bucharest, Romania

${ }^{2}$ Faculty of Railways, Roads and Bridges, Technical University of Civil Engineering of Bucharest, carmen.racanel@utcb.ro

${ }^{3}$ Politehnica University of Bucharest

Received: 17.10 .2019

Accepted: 17.03 .2020

https://doi.org/10.24264/Ifj.20.1.3

RESEARCH ON THE USE OF TANNED LEATHER FIBRES AS AGGREGATE IN OBTAINING ASPHALT MIXTURES

ABSTRACT. The current tendency of road builders and managers is to make asphalt mixtures with improved performance in terms of aging and fatigue resistance, better traffic behavior both in summer and in winter, as well as increased values for dynamic properties: elasticity, tracking, etc. In this sense, there is a permanent concern to find new materials and technologies for the preparation and implementation of asphalt mixtures that convey the desired properties to the layers. In this sense, the addition of microfibres and fibres, with dimensions ranging from 0.01-10 mm when preparing asphalt mixtures, transforms the bituminous binder used into a "composite material", in which the matrix is the bitumen, and fibres are the dispersed phase, leading to the stabilization of the bitumen inside the mix, as well as to the reinforcement of the asphalt mixtures, giving them special properties. The paper presents laboratory experiments for obtaining smart biocomposites (leather fibres-asphalt mixtures) with applications in the field of road infrastructure. The resulting biocomposites were characterized by chemical, physical-mechanical and structural analyses.

KEY WORDS: asphalt mixture, tanned leather fibres, biocomposites, leather waste

\section{CERCETĂRI PRIVIND UTILIZAREA FIBRELOR DE PIELE TĂBĂCITĂ CA AGREGAT ÎN OBTINEREA MIXTURILOR ASFALTICE}

REZUMAT. Tendinţa actuală a constructorilor şi administratorilor de drumuri este de a realiza mixturi asfaltice rutiere cu performanţe îmbunătăţite în ceea ce priveşte rezistenţa la îmbătrânire şi oboseală, comportare mai bună în trafic atât vara, cât şi iarna, precum şi valori crescute pentru proprietăţi dinamice: modul de elasticitate, ornieraj, etc. în acest sens, există o preocupare permanentă de a găsi noi materiale şi tehnologii de preparare şi punere în operă a mixturilor asfaltice, care să confere straturilor realizate proprietăţile dorite. În acest sens, adaosul de microfibre şi fibre, cu dimensiuni cuprinse între 0,01-10 mm la prepararea mixturilor asfaltice, transformă liantul bituminos utilizat într-un „material compozit”, în care matricea o reprezintă bitumul, iar faza dispersă fibrele, conducând atât la stabilizarea bitumului în interiorul mixturii, precum şi la armarea mixturilor asfaltice, conferindu-le acestora proprietăţi speciale. În lucrare se prezintă experimentări de laborator de obţinere a biocompozitelor inteligente (fibre de piele-mixturi asfaltice) cu aplicaţii în domeniul infrastructurii rutiere (şosele). $\mathrm{S}$-a realizat caracterizarea prin analize chimice, fizico-mecanice şi structurale a biocompozitelor obţinute.

CUVINTE CHEIE: mixtură asfaltică, fibre de piele tăbăcită, biocompozite, deşeuri de piei

RECHERCHE SUR L'UTILISATION DES FIBRES DE CUIR COMME AGRÉGÉES POUR OBTENIR DES MÉLANGES ASPHALTIQUES

RÉSUMÉ. La tendance actuelle des constructeurs et gestionnaires de routes est de réaliser des mélanges d'asphalte routier avec des performances améliorées en termes de résistance au vieillissement et à la fatigue, un meilleur comportement dans la circulation en été comme en hiver, ainsi que des valeurs accrues pour les propriétés dynamiques : module d'élasticité, orniérage, etc. En ce sens, il y a un intérêt permanent de trouver de nouveaux matériaux et technologies pour la préparation et la mise en œuvre des mélanges d'asphalte, qui confèrent aux couches réalisées les propriétés souhaitées. À cet égard, l'ajout de microfibres et de fibres, avec des dimensions allant de 0,01 à $10 \mathrm{~mm}$ lors de la préparation des mélanges d’asphalte, transforme le liant bitumineux utilisé en un "matériau composite", dans lequel la matrice représente le bitume, et les fibres la phase dispersée, conduisant à la fois à la stabilisation du bitume à l'intérieur du mélange, ainsi qu'au renforcement des mélanges d'asphalte, leur conférant des propriétés particulières. L'article présente des expériences de laboratoire pour l'obtention de biocomposites intelligents (fibres de cuir-mélanges d'asphalte) avec des applications dans le domaine des infrastructures routières. Les biocomposites obtenus ont été caractérisés par des analyses chimiques, physico-mécaniques et structurelles. MOTS CLÉS : mélange d'asphalte, fibres de cuir, biocomposites, déchets de cuir

* Correspondence to: Gabriel ZĂINESCU, INCDTP - Division: Leather and Footwear Research Institute, 93 Ion Minulescu Str., 031215, Bucharest, Romania, gabriel.zainescu@gmail.com 


\section{INTRODUCTION}

In the field of road infrastructure, the current tendency is to make road structures from composite asphalt mixtures, in which, besides the classical materials, fillers or reinforcement materials are added, generally in the form of powders, granules, fibres, yarns. These new materials can be of the most diverse classes of chemical compounds, both inorganic (glass, asbestos, ceramic) and organic (natural and synthetic polymers).

The presence of fibres in an asphalt mix creates a true "interpenetrating network" that allows the distribution of stresses within the matrix and fibres. Therefore, these composite asphalt mixtures are an appropriate solution for preventing the transmission of cracks, increasing the resistance to aging and fatigue and reducing the rapid degradation of road layers [1].

Cracks often occur in the wear layer, having a set of causes, including the low tensile strengths of the constituent mixtures, a phenomenon that can be prevented by different methods and technologies. One of these methods is to use the principle of dispersed reinforcement of asphalt concrete, using different fibres as reinforcement $[2,3]$.

Selection of the asphalt mixture type from which the bituminous coating is to be made is of great technical and economic importance. Asphalt concretes are mixtures made of chippings, sand, filler, agglomerated with bituminous binder, using an appropriate hot mixing technology. Asphalt concrete can be designed and manufactured in a great diversity, depending on requirements, and with high physical-mechanical characteristics, which will ensure a long operating life for the wear layer [4]. Thus, the most used are asphalt concrete rich in chippings, BA 16-type and called BAA16 (fibre reinforced asphalt concrete). These types of bituminous coatings can be reinforced with fibres and yarns of different classes of chemical compounds.

Another type of mixture used more and more often in the roads abroad, but also in our country, is the asphalt mix with cellulose fibre, MASF 16-type, a mix based on a special SMA Stone Mastic Asphalt formulation.

SMA is a formulation characterized by the roughness of the crushed aggregates, of high granulation, found in an amount of $70-80 \%$, due to the higher content of bitumen (6.7-7.0\%) and stabilizing additive with cellulose fibres $[5,6]$. The aggregates are constituted in a framework of resistance in the hollows of which there is a viscous filling of bituminous mastic, additivated with cellulose fibres. Reinforcement using fibres does not allow the bitumen to deteriorate at extreme temperatures, either hot or cold, without compromising on its efficiency [7].

The advantages of using this type of asphalt concrete:

- high stability at permanent deformations;

- the aggregates give the structure of resistance;

- transmission of road loading forces is done from aggregate to aggregate, to the lower layers and then to the ground;

- good resistance to wear, fatigue, aging;

- drainage of water;

- rough surfaces (increases slip resistance and noise absorption by $2-4 \mathrm{~dB}$.

These types of asphalt concrete can be used both on the wear layers, as well as on the connecting layers and the bridge road.

The fibres most used in the establishment/ reinforcement of asphalt mixtures are natural fibres: cellulose, polypeptides, glass fibres, and synthetic polyacrylonitrile (PNA), polypropylene yarns [8]. Generally, the dimensions of these fibres are of the order of microns and their absorption in bitumen (due to the dimensions comparable to the bitumen particles) stabilizes/ stiffens it, transforming it into mastic, and in the case of yarns with millimetric dimensions, they reinforce the mix by creating a discontinuous three-dimensional network. The optimum amount of fibre to be added to the asphalt mixture is between $0.25-0.5 \%(0.3 \%)$.

\section{Asphalt Mixtures Improved by the Use of Modified or Additivated Bitumen}

Studying and obtaining of asphalt mixtures with superior mechanical performances are necessary to make road layers with special characteristics and well-defined uses, of which we mention:

- obtaining asphalt mixtures that can be put into operation in thin layers, presenting a great roughness; these will be used especially for the maintenance of existing coatings; 
- making asphalt mixtures capable of supporting larger deformations under repeated efforts, which would be used for:

- coating with thin bituminous layers (3 $\ldots 5 \mathrm{~cm}$ ) of worn coating that shows contraction cracks, crazing due to fatigue of the material, etc.;

- reinforcing existing road structures, especially in cities where it is not possible to apply thick layers to existing coating;

- resistant coating for bridge roads;

- maintenance of the existing coating, by applying asphalt layers of small thickness;

- the application of asphalt layers from special asphalt mixes on cracked cement coating;

- bituminous coatings made from composite asphalt mixtures with additions of natural and synthetic fibres.

The category of special bituminous coatings with superior characteristics includes coatings made of asphalt mixtures with bitumen with rubber and bitumen with polymers as binder. Bituminous coatings made from asphalt mixtures based on bitumen with additives (BA16a) aim to increase the adhesion of bitumen to the natural aggregates and the possibility of using them for ballast aggregates or less processed by crushing.

In conclusion, it is mentioned that the asphalt mixtures with bitumen modified with polymers $(\mathrm{Bm})$ or with additivated bitumen $(\mathrm{Ba})$, due to the high level of their performance, allow the production of efficient bituminous coating under severe stress conditions. The use of BA16a- and BA16m-type asphalt mixtures, which use synthetic fibres and yarns for the purpose of reinforcing and increasing performance at wear, fatigue (BAA16a and BAA16m) is recent, but they tend to expand rapidly, both for the wear layers, but also for the connection ones [7].

\section{EXPERIMENTAL}

\section{Making Composite Asphalt Mixtures in the Laboratory}

INCDTP - Division: ICPI together with the Technical University of Civil Engineering of Bucharest, the Faculty of Railways, Roads and Bridges, have conducted an experimental study in order to use leather fibre waste in the asphalt mixture for the road layer.

In this sense, at first a formulation for asphalt mixture designed from the point of view of the dosages of the component materials, in the Roads Laboratory of the university was considered.

Thus, the stabilized MAS 16-type asphalt mixture was selected, which can be used in the wear layer of the road structure. This asphalt mixture is composed of aggregates from the Morlaca quarry, filler from the Alesd factory, D50/70 bitumen from Poland, cellulose fibres produced by Iterchimica Italy, and an additive produced by Atica Chemicals was used as a binder.

Starting from this asphalt mixing recipe, cellulose fibre was replaced with enzymatically tanned treated leather fibre. The granularity of the aggregate and the filler in the MAS16 formulation are presented in Table 1, while Figure 1 presents the diagram of the granulometric curve of the MAS 16 asphalt mixture according to AND 605 norm of 2016.

Table 1: Granularity of aggregates and filler according to SR EN 933-1

\begin{tabular}{|c|c|c|c|c|c|c|c|c|c|c|}
\hline \multirow[t]{2}{*}{ Aggregate (mm) } & \multicolumn{10}{|c|}{ Residue on the sieve of ...mm, [\%] } \\
\hline & 16 & 12.5 & 11.2 & 8 & 4 & 2 & 1 & 0.125 & 0.063 & $<0.063$ \\
\hline Chippings, size $8-16$ & & 33.52 & 22.92 & 43.55 & & & & & & \\
\hline Chippings, size $4-8$ & & & & & 100.00 & & & & & \\
\hline Crushing sand, size $0-4$ & & & & & & 33.80 & 21.00 & 34.80 & 4.20 & 6.20 \\
\hline Filler & & & & & & & & 8.80 & 14.90 & 76.30 \\
\hline
\end{tabular}




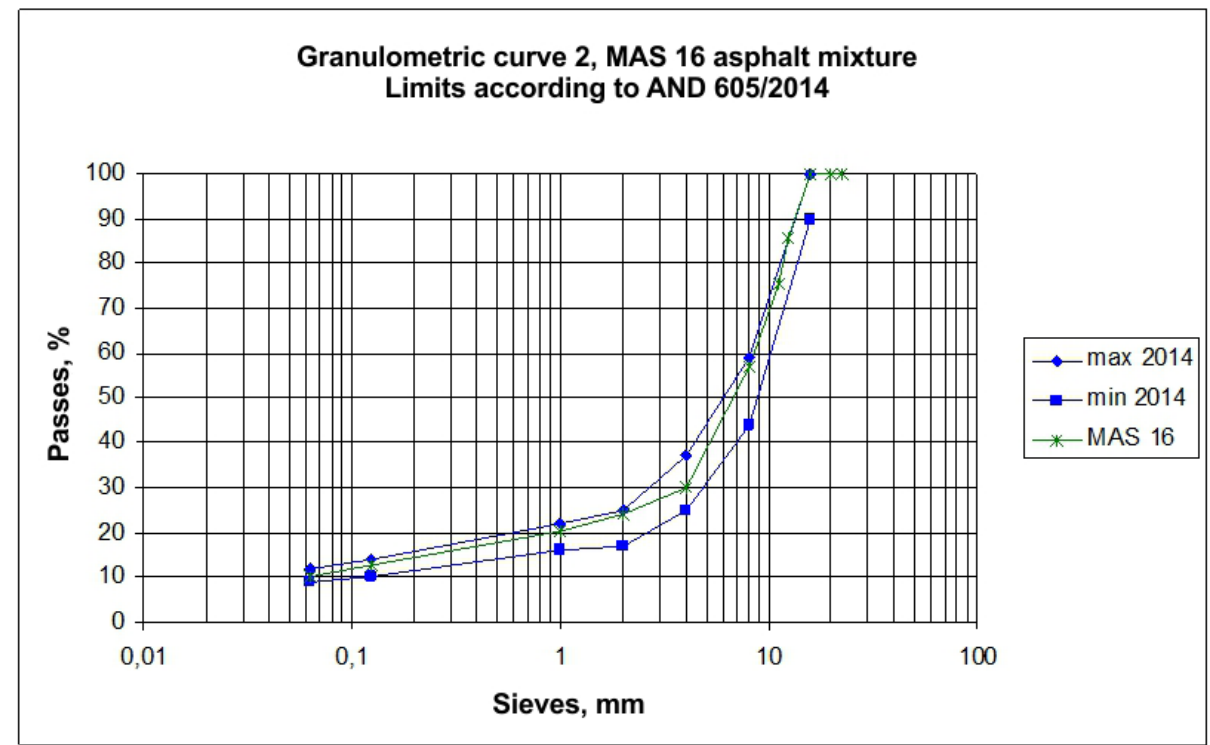

Figure 1. Diagram of the projected curve of the aggregate mixture in the granulometric area according to norm AND 605

In order to establish an optimal percentage of leather fibre and keep the bitumen percentage of the initial recipe unchanged $(5.9 \%$ - minimum value according to the regulations in force), the Schellenberg binder drainage test was performed, according to the following values:
$0 \%, 0.4 \%, 0.5 \%, 0.6 \%, 0.7 \%, 0.8 \%$ and $2 \%$ (Table 2 ). The fibre percentage of $2 \%$ was chosen, complying with the standard condition, for which a value of $0.1 \%-0.2 \%$ was obtained (minimum value from AND 605).

Table 2: Establishing the optimal percentage of leather fibre in the mixture composition

\begin{tabular}{|c|c|c|c|c|}
\hline \multirow[t]{2}{*}{ Formulation } & \multirow{2}{*}{$\begin{array}{c}\text { Bitumen, } \\
\%(\mathrm{M})\end{array}$} & \multirow{2}{*}{$\begin{array}{l}\text { Fibre, } \\
\%(\mathrm{M})\end{array}$} & \multicolumn{2}{|c|}{ Schellenberg test, D, \% } \\
\hline & & & $\begin{array}{l}\text { Resulting } \\
\text { value }\end{array}$ & $\begin{array}{l}\text { Value rounded to } 0.1 \% \text {, } \\
\text { according to SR EN } 12697-18\end{array}$ \\
\hline \multirow[t]{7}{*}{ Granulometric curve 2, C2 } & 5.9 & 0 & 0.975 & 1 \\
\hline & & 0.4 & 0.82 & 0.8 \\
\hline & & 0.5 & 0.775 & 0.8 \\
\hline & & 0.6 & 0.74 & 0.7 \\
\hline & & 0.7 & 0.72 & 0.7 \\
\hline & & 0.8 & 0.67 & 0.7 \\
\hline & & 2 & 0.075 & 0.1 \\
\hline
\end{tabular}

Next the maximum density of the mixture, the apparent volume mass (apparent density) on Marshall-type samples (cylindrical samples with $\mathrm{h} \sim 63.5 \mathrm{~mm}$ and $\mathrm{F}=101 \mathrm{~mm}$, compacted using the Marshall extruder), the volume of holes in the compacted mixture and the volume of holes filled with bitumen (both calculated for Marshalltype samples) were determined.

Figure 2 shows the optimal bitumen content in the leather fibre formulation using the Marshall extruder. 


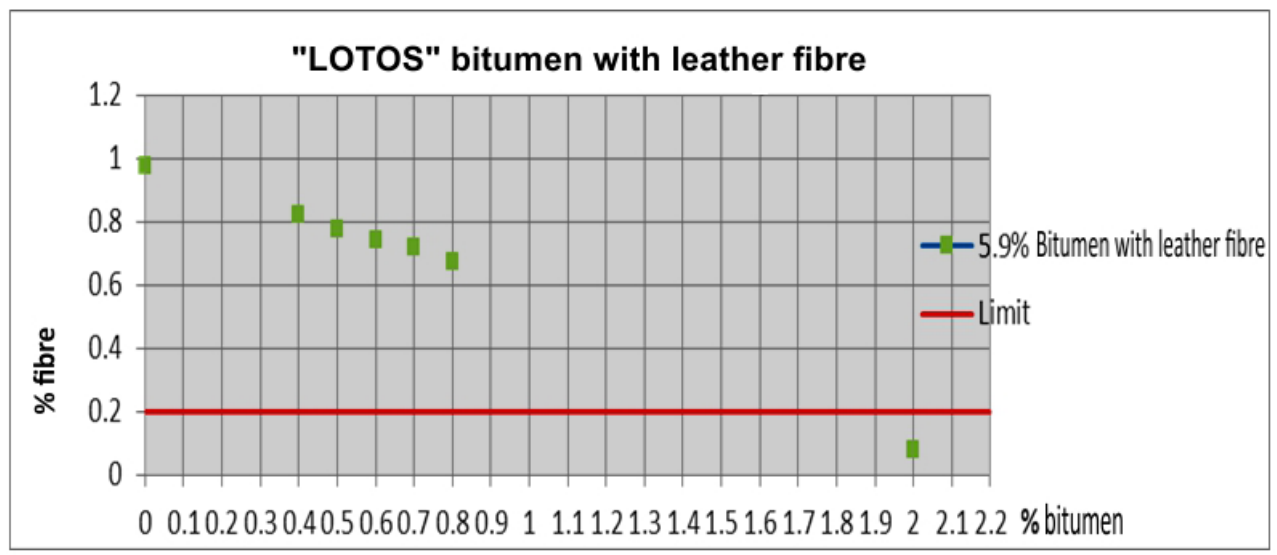

Figure 2. Determining the optimal bitumen content in the leather fibre mixture

The C2-MAS 16 formulation with 5.9\% bitumen, containing $0.4 \%$ Atica ABR-1 additive

(in relation to bitumen) $+2 \%$ leather fibre is presented in Table 3.

Table 3: Ingredients of the formulation for asphalt mixture with $2 \%$ leather fibre

\begin{tabular}{llc}
\hline No. & \multicolumn{1}{c}{ Material } & Dose (\%) in mixture \\
\hline 1. & Chippings, size 8-16 & 39.6 \\
2. & Chippings, size 4-8 & 24.87 \\
3. & Crushing sand, size 0-4 & 16.58 \\
4. & Filler & 11.05 \\
5. & Bitumen & 5.876 \\
6. & Atica ABR-1 additive & 0.024 \\
7. & Leather fibre & 2 \\
8. & Total & 100.00 \\
\hline
\end{tabular}

Table 4 presents the physico-mechanical characteristics of the laboratory-prepared mixture for the formulation selected for experimentation, these complying with the requirements of the standards and norms in force. In addition to the above, determinations were made to establish the stiffness modulus at $20^{\circ} \mathrm{C}, \mathrm{IT}-\mathrm{CY}$ and the apparent volumetric mass, on Marshall cylindrical samples, made in the rotary press (gyro-compactor), as well as to determine behaviour to the destructive action of water: ITSR test (water sensitivity) on Marshall cylindrical samples (made using Marshall extruder) according to AND 605 norm.

Table 4: Physical-mechanical characteristics of the asphalt mixture made in laboratory

\begin{tabular}{clccc}
\hline No. & \multicolumn{1}{c}{ Formulation } & Control & $\begin{array}{c}\text { Fibre, } \\
2 \%(\mathrm{M})\end{array}$ & $\begin{array}{c}\text { Technical conditions } \\
\text { according to AND 605 }\end{array}$ \\
\hline 1. & Maximum density of asphalt mixture, $\mathrm{Mg} / \mathrm{m}^{3}$ & 2.353 & 2.452 & \\
2. & Apparent volume mass, $\mathrm{kg} / \mathrm{m}^{3}$ & 2295 & 2364 & - \\
3. & Volume of holes in compacted Marshall samples, $\mathrm{Vm}, \%$ & 2.47 & 3.58 & $3 \ldots .4$ \\
4. & Volume of holes filled with bitumen, VFB, $\%$ & 79 & 83 & $77 \ldots 83$ \\
5. & Water sensitivity (method A), \% & 84 & 89 & $\min .80$ \\
6. & Stiffness modulus, at $20^{\circ} \mathrm{C}, \mathrm{MPa}$ & 5978 & 3893 & $\min .4200$, class I-II \\
& & & & min. 4000, class III-IV \\
\hline
\end{tabular}

The ICPI asphalt mixture, made in the asphalt station of S.C. Tancrad Galati, is a MASF16 mixture (asphalt mixture stabilized with fibres) using Turcoaia aggregates and ESSO bitumen following an average granulometric curve. The
ICPI asphalt mixture formulation was as follows: chippings $8-16 \mathrm{~mm}-32.5 \%$; chippings $4-8 \mathrm{~mm}$ - 23.0\%; crushing sand $0-4 \mathrm{~mm}-32.0 \%$, filler $8.8 \%$, bitumen $-5.7 \%$.

Finally, the IT-CY stiffness modulus was 
determined, at $20^{\circ} \mathrm{C}$ on cylindrical samples made using Marshall extruder for two mixtures made in ICPI: one of them without fibres, the second, with $3 \%$ leather fibres. Both asphalt mixtures are made of the same materials and have the same granularity and the same percentage of bitumen. A higher value of stiffness modulus is noticed for the mixture with leather fibres.
As shown in Table 5, the ICPI mix has improved Marshall features, from $4200 \mathrm{MPa}$ to $7660 \mathrm{MPa}$, which shows that it is a flexible mix with low deformability, high workability and a very good compaction compared to a control mix.

Table 5: Physical-mechanical characteristics of ICPI asphalt mixture (average values)

\begin{tabular}{|c|c|c|c|c|c|}
\hline No. & Determination & UM & $\begin{array}{l}\text { ICPI asphalt mixture } \\
\text { without fibre, control }\end{array}$ & $\begin{array}{l}\text { ICPI asphalt } \\
\text { mixture with } \\
\text { fibre }\end{array}$ & $\begin{array}{c}\text { Technical conditions according } \\
\text { to AND } 605\end{array}$ \\
\hline \multicolumn{6}{|c|}{ Trials on Marshall-type cylindrical samples } \\
\hline 1. & $\begin{array}{l}\text { Apparent } \\
\text { volumetric mass }\end{array}$ & $\mathrm{kg} / \mathrm{m}^{3}$ & 2410 & 2360 & - \\
\hline 2. & $\begin{array}{l}\text { Stiffness modulus } \\
\text { at } 20 \stackrel{\circ}{ }{ }^{\circ}, 124 \mathrm{~ms}\end{array}$ & $\mathrm{MPa}$ & 3893 & 7660 & $\begin{array}{l}\text { min. } 4200, \text { Technical class: road } \\
\text { I-II and } \\
\text { min. 4000, Technical class: road } \\
\text { III-IV }\end{array}$ \\
\hline
\end{tabular}

Figure 3 shows the gyratory compactor used to determine the stiffness modulus on cylindrical samples of asphalt mixtures and test diagrams.
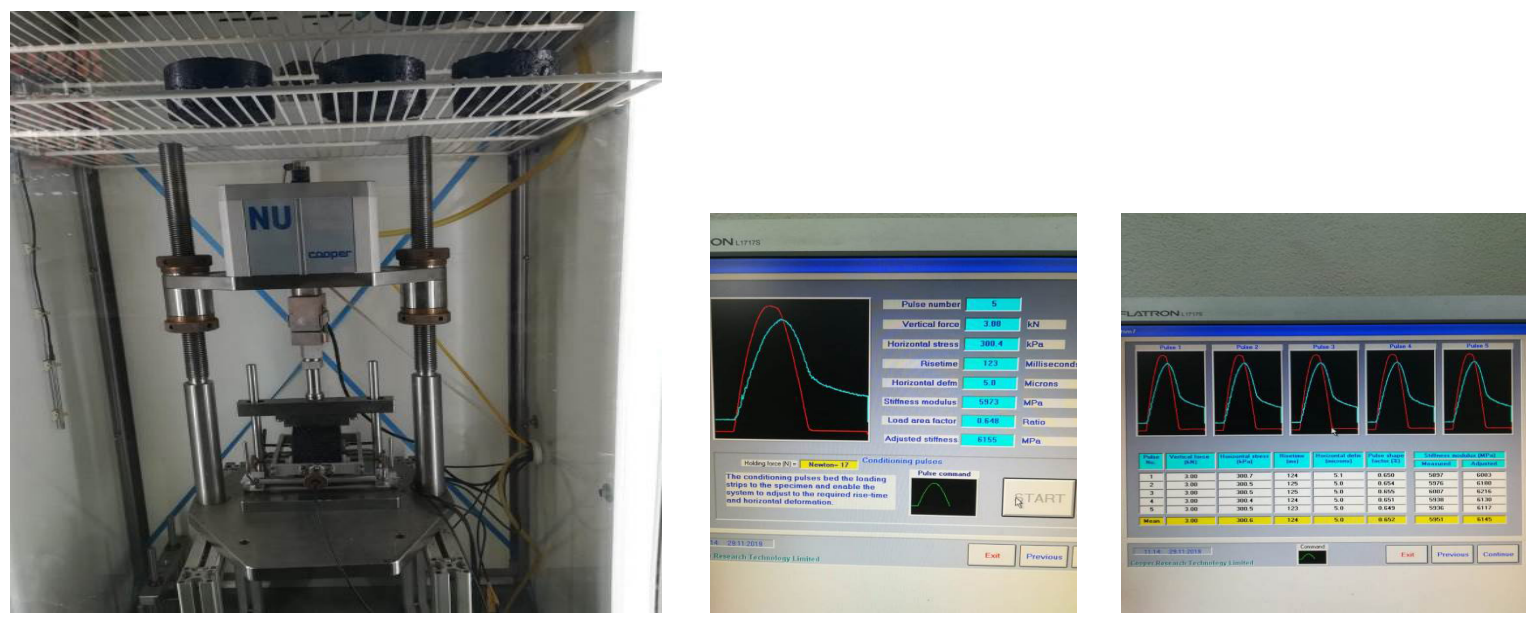

Figure 3. Determination of stiffness modulus on cylindrical samples, IT-CY

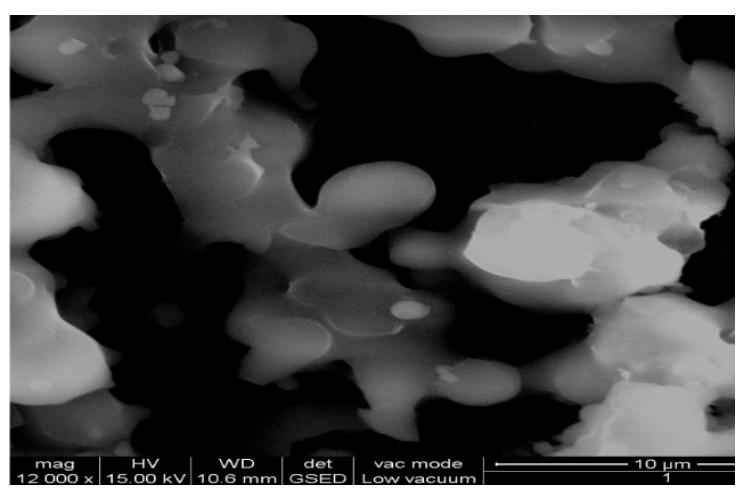

b

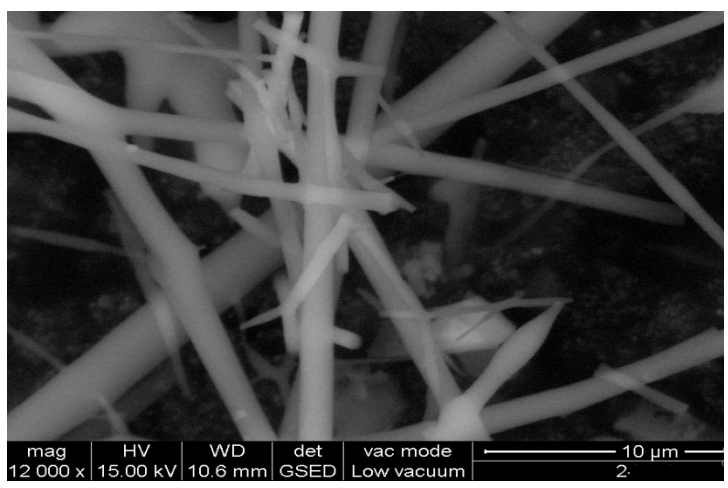

Figure 4. Electron microscopy images of asphalt mixtures - magnitude $12000 \mathrm{x}$ : a) control, b) sample 
ICPI asphalt mixtures with and without fibres were studied by SEM electron microscopy (with a magnification of $12,000 \mathrm{x}$ ) at the Institute of Atomic Physics, to evaluate the surface morphology and to highlight the leather fibre content (Fig. 4).

The resulting characteristics prove that the solution of an asphalt mixture stabilized with leather fibres is a feasible one, considering that all the results are in compliance with the requirements of the norms in force.

\section{CONCLUSIONS}

The paper presents a formulation for asphalt mixture, in which cellulose fibre was replaced with enzymatically treated leather fibre, as well as the granulometric curve of the aggregate and the filler from the MAS16-type formulation.

In order to establish an optimal percentage of leather fibre and keep the bitumen percentage of the initial formulation unchanged (5.9\% minimum value according to the regulations in force), the Schellenberg binder drainage test was performed, for eight samples of asphalt mixture with different percentages of leather fibre content, according to the following values: $0 \%$, $0.4 \%, 0.5 \%, 0.6 \%, 0.7 \%, 0.8 \%, 2 \%$ and $3 \%$.

Eight asphalt mixtures were obtained with different fibre percentages (0.4-3\%), of which, according to SR EN 933-1, two variants were selected by Schellenberg test (with 2\% and 3\% leather fibre content). For these biocomposites, the IT-CY stiffness modulus was determined, at $20^{\circ} \mathrm{C}$ on cylindrical samples made using Marshall extruder, obtaining significantly higher results for asphalt mixtures with leather fibre.

In order to evaluate the surface morphology and to highlight the leather fibre content, ICPI asphalt mixtures with and without fibres were studied by SEM electron microscopy.

In conclusion, it can be argued that the solution of an asphalt mixture stabilized with leather fibres is a feasible one, considering that all the technical results are in compliance with the requirements of the norms in force.

\section{REFERENCES}

1. Krummenauer, K., Jairo, J., Andrade, O., Incorporation of chromium-tanned leather residue to asphalt micro-surface layer, Constr Build Mater, 2009, 23, 574-581, https://doi. org/10.1016/j.conbuildmat.2007.10.024.

2. Patchai, M.K., Swarnalatha, S., Sekaran, G., Utilization of Micro Fibrous Carbon Matrixfrom Tannery Solid Waste for Making Pavement Materials, International Conference on Solid Waste Management, Procedia Environ Sci, 2016, 35, 298-307, https://doi.org/10.1016/j. proenv.2016.07.010.

3. Wu, S., Ye, Q., Li, N., Investigation of rheological and fatigue properties of asphalt mixtures containing polyester fibers, Constr Build Mater, 2007, https://doi.org/10.1016/j. conbuildmat.2007.07.018.

4. Chen, J.S., Lin, K.L., Mechanism and behavior of bitumen strength reinforcement using fibers, J Mater Sci, 2005, 40, 87-95, https:// doi.org/10.1007/s10853-005-5691-4.

5. Tapkin, S., The effect of polypropylene fibers on asphalt performance, Build Environ, 2007, 43, 6, 1065-1071, https://doi.org/10.1016/j. buildenv.2007.02.011.

6. Putman, B.J., Amirkhanian, S.N., Utilization of waste fibers in stone matrix asphalt mixtures, Resour Conserv Recy, 2004, 42, 265-74, https://doi.org/10.1016/j. resconrec.2004.04.005.

7. Associação Brasileira de Normas Técnicas. NBR 6570: Emulsões asfálticas - Determinação da sedimentação, Rio de Janeiro, 2000, p. 3.

8. Zainescu, G., Constantinescu, R., Ciobotaru, C.O., Pang, X., Value-Added 
Smart Biocomposites Based on Chrome Leather Fibres and Recyclable Rubber, 8th International Conference on Environment, Chemistry and Biology (ICECB 2019), 19-21 November, 2019, Paris, pp. 31-37.
(C) 2020 by the author(s). Published by INCDTPICPI, Bucharest, RO. This is an open access article distributed under the terms and conditions of the Creative Commons Attribution license (http://creativecommons.org/licenses/by/4.0/). 